\title{
Coexistence in Modernity: A Euromed Perspective
}

\author{
$\propto$ HenRY FRendo $\propto$
}

\begin{abstract}
A BSTRACT Does cultural diversity lead to a want of respect, intolerance, and violence? Is religious culture in Islamic or other states tending towards a territorial imperative, denying any democracy a chance? Is globalization threatening value, identity and meaning? In the wake of 9/11, war on the Taliban's Afghanistan and Saddam's Iraq, the lingering Israeli-Palestinian tension, and what appear to be re-discovered genres of brutality-such as suicide bombings, beheadings, the wanton destruction of churches and other temples- this article teases out some historical and philosophical contexts in an attempt to assuage contemporary uncertainties. Distinguishing between the Mediterranean and the Middle East as two different realities, the article discusses how seemingly bewildering new theses and premises in a post-war, post-colonial, postcommunist world may be read and possibly reconciled during the twenty-first century.
\end{abstract}

In Herder's time, the philosophes of the French Enlightenment made a clear distinction between those societies that had attained a higher plane of civilization and those who languished as barbarians. According to Windshuttle's critique of Kelley's historical inquiry from Herodotus to Herder, "Herder's cultural relativism, however, would have none of this. There could be no barbarians since all cultures were authentic.",

Inspired by Albin Michel's study Ou sont le valeurs, which it published, UNESCO recently held a conference on the future of values which, not surprisingly, if more cautiously, came to much the same conclusion: "All cultures are equal in dignity," said in summary its director-general Koichiro Matsuura. "Each can be seen as embodying part of the human totality. All countries must therefore be respected, which in no way means that all actions are permissible and all crimes justified in the name of cultural diversity... Every culture comprises individuals and groups who distinguish between what is just and unjust and make their evaluations accordingly.",

Culture and country; justice and injustice; belief and disbelief... Herder's point was moreover that, in contrast to the civilization of scholars and philosophers, culture could involve the whole people (kultur des volkes) and so represented the best road to an understanding not only of history but also of human nature.

The inquisitive tensions between nationality and universality, cultures and civilizations, which go back to ancient times, are one of the concerns in Ibn Khaldoun's

University of Malta, Department of History, Room 203 Humanities Building, Msida Campus, Msida MSD06, Malta. Email: henry.frendo@um.edu.mt 
Muqaddima in the fourteenth century, as he grapples with devising a science of culture, the trend of events, inner social laws on the masses which cannot be influenced significantly by isolated individuals, operating organically across societies with the same kind of structure, as in national characters and the characteristics of social groups deriving partly from occupations and environments. When it came to religion, nonetheless, he took care to delineate the limits of reason, which largely stopped at the gates of theology. More tellingly, he saw how religion, Islam in his case, could bolster social cohesion ('asabiya), whereby great empires could thus be founded. ${ }^{3}$ Nor was this fact lost on other religions, victorious or vanquished: one millennium before Ibn Khaldoun another North African, Augustine, was moved to write the City of God, in reply to pagan criticism, just after the fall of Rome to Alaric, a Visigoth and an Arian.

Empire and counter-empire; fall and resurrection; darkness and rebirth; depression and recovery...

One geopolitical area retaining aspects of a socio-environmental commonality, which long has focussed and inspired thinkers and writers - from Strabo to Burkhardt, Pirenne to Braudel - has been the Mediterranean, to the point that Burkhardt in the 1950 s described the whole region up to the Persian Gulf as "one animate being," whereas Braudel continued to insist into the 1970s not only that the Turkish Mediterranean "lived and breathed with the same rhythms as the Christian" but that "the whole sea shared a common destiny." How whole, how shared and how common any such destiny is today remains a trifle uncertain. Without being deterministic or holistic, in this presentation I shall try to argue that in spite of strong outside forces penetrating - aiding and disrupting-slow-moving continuity-and-change mouldings, at least a part of the Mediterranean could still conceivably retain the potential for intelligible and functional unities, with possibly a growing interaction between the northern and southern shores, in spite of - and, to an extent, because of - the more globalized, consumerist, telecommunicated "juggernaut" which, according to Giddens, renders all relationships distant, inanimate and risky. This tentative, problematic approach, less optimistic and romantic but also less pessimistic than contemporary goings-on would suggest to the point of an impending absurd self-destruction, hopefully goes beyond wishful thinking and points to some still possible engagement in the foreseeable future.

It is the height of historical irony that the co-existence of differences should appear so tenuous in our own "modern" or "post-modern" times, when it would have seemed that three nightmares haunting the second half of the twentieth century had been exorcised.

The first of these was a total war, starting in central Europe, circling the earth, leading to unprecedented destruction and devastation by sophisticated weaponry, an organized genocide, and the dropping of atomic bombs for the first time, so far.

The second was a protracted, sometimes very bloody South-North struggle against European territorial imperialism and colonialism, especially in Africa and Asia, but also very much on the borders of the European mainland itself, in the Mediterranean region.

The third was the dismantling of what had become a post-war norm, an East-West military-ideological divide across the European continent, with repercussions far beyond it, polarizing the world between "American" capitalism and "Soviet" communism, with each bloc's orbit of "satellites." 
In the industrialized world, post-war reconstruction slowly but surely led to a welfare state in varying degrees and through different systems-liberal, proletarian and others in between - albeit not everywhere to the same extent, certainly. Western Europe, which had also witnessed a major civil war, gradually saw a transition from totalitarian or authoritarian regimes to constitutional parliamentary democracies. In the determination never again to permit what had occurred between neighbouring states who were in other ways heirs to a shared civilization - however diverse and distinct in its particulars, but here in Pamplona recall the trans-frontier pilgrimage to Compostella-a new hope and much creative solidarity came to the fore. Traditional conflict stratagems among states would be replaced by inculcated perceptions of common interest, and these institutionalized in turn through extra-national structures, agreed and adhered to by a territorially and economically centred political community of nations, on the Jean Monnet principle. There was an accompanying cultural resurgence inspired by the realization that, as Denis de Rougemont put it, Europeanity could internalize a habeas corpus as well as a habeas animam. Democratic stability favoured peace and facilitated prosperity, but integration also helped-even as diehard nationalists felt threatened in their ways by such a new order.

If only by default, reconstruction and reconciliation "at home" were accompanied by a hurried retreat from empire through a decolonization forced upon the formerly expansionist European powers by a web of post-war circumstances, economic, political or indeed military. Increasingly vociferous nationalist parties and movements from Ghana to Iraq to Indochina-some of whose countries had been literally carved up with invented borders on the map as suited the occupying powers-demanded their national sovereignty (whether they had ever had such a thing or not) as independent nation-states. Once again, amidst the dancing and singing, independence aroused new hopes and prospects. And fears. Contrary to patriotic expectations, it soon would be realized that, in too many cases, independence led neither to internal freedom nor to structured development. That predicament would come to include some of the potentially richest and best-served countries on earth, one of the latest victims being Mugabe's Zimbabwe after 1980, and, still worse, more organized genocide at the end of the twentieth-century - in Yugoslavia-such as had ended the nineteenth, on a still larger scale-in Armenia. Post-colonial Africa and Asia saw some horrific scenarios, in at least one of which, in Sudan, the blood has not dried. In some other countries, bold attempts at a self-dignified national revival were accomplished-even if not perhaps as prosperous, or as alienated, by Western liberal capitalist standards. So far as Europeans were concerned, however, they generally felt that they no longer had a direct stake or say in such goings-on; they were out. They could ride into the sunset and retreat from the foray, maintaining only such links as were mutually beneficial, if possible. Or so it seemed, initially.

The third and most recent stage in this would-be conclusive modern evolution was the end of the Cold War, the dismantling of the Berlin Wall in the bicentennial year of the French Declaration of the Rights of Man and of the Citizen, followed by the reunification of Germany and, equally, the sudden collapse of communism as an ideology and a system of governance. Instead, as we know, Europe witnessed the gradual, in cases painful, emergence or resurgence of democratically-based, democratically-aspiring states in Eastern Europe and the Balkans. The one-time Coal and Steel Community 
turned Common Market, since Maastricht a European Union, as of 1 May 2004 came to comprise as many as 25 member states, with golden stars on blue symbolizing hope for this reunified, newly-integrating, and differently expanding continental set-up.

In 2001, however, any Western complacency was shell-shocked into disbelief and disquiet by September 11 in New York and Washington, and subsequently, in 2004, by March 11 in Madrid. If the former was "an earthquake of the collective psyche," as Halliday has described it, ${ }^{5}$ Madrid showed how active this moving volcano still was. During the Gulf War a decade earlier it had seemed that a US-led coalition with the UN's blessing had rushed to the defence of a small state, swallowed up by a larger neighbour, although the offending state, Iraq, survived under the same leadership with dents and bruises. Just about Iraq's only Middle East ally in that war, which saw Scud missiles fired at a non-combatant state, was Yasser Arafat's PLO. In the meantime, resentment against the West, for which read mainly the USA, was simmering, even intensifying, in at least some quarters of the largely Islamic Middle East and South Asia. The other constant, which deteriorated further and reached new lows after 2000, was the Israeli-Palestinian conflict-two leading regional peace-brokers, President Sadat and Prime Minister Rabin, had been assassinated. And it is arguably this, more than any other single factor, which fanned the flames in a newly-forming anti-American dynamic that insidiously came to take in with it, the whole of Europe, the so-called West, Christendom, secular lifestyles, even democracy, in the firing line.

As expected by many, the US invasion of Iraq in 2003, undertaken partly on misinformed intelligence, may have removed Saddam Hussein, but so far its aftermath seems headed towards at best an uncertain future, unleashing or serving as a pretext for some of the most ruthlessly brutal, gruesome crimes, many of them against innocent civilians and locals, all supposedly committed, unbelievingly, in the name of Allah. And all largely directed at Americans, and at whomsoever is held to cooperate with them, directly or indirectly, in the rebuilding and democratization of post-Saddam Iraq, including the UN. One wonders if $\mathrm{Al}$ Qaeda, dislodged from Afghanistan, has not targeted Iraq as its next base; but there are too many conspiracy theories being spun, and chaos, to know anything much for sure. Even the beheadings shown on Al Jazeera's TV seem surreal, not unlike the sight on CNN of the Twin Towers melting down in a gigantic puff of smoke, in what could have been taken for a Hollywood extravaganza. Symbolically again, we had the dim-witted "planting" of the US flag on a one-time monument to Saddam, the first to be pulled down in Baghdad; and the sadistic abuse of naked charges by Anglo-American prison wardens supposedly representing the moral high ground. On Sunday 1 August 2004 six old-established Iraqi Christian churches were simultaneously targeted, an outrage condemned by the leading Shi'a moderate as-Sistani; but given that the Pope more than any other international leader so repeatedly implored President Bush, even to his face, not to invade Iraq, apparently it is not God who is dead but Reason-in the face of a total intolerance of difference, let alone dissidence. One is tempted to exclaim with that nineteenth-century painter of storms, Turner, troubled as he was by horrors such as slavers throwing human cargo overboard: "Hope, hope, fallacious hope, where is thy market now?"6

In this disturbing contemporary context, talk of co-existence has become more difficult and nuanced. Just at the moment when the world, or at least the "West," seemed 
poised to take off into a new era of peace, facilitating cooperation and salutary housekeeping measures to improve the lot of ordinary citizens, it has been plunged into what appears to be a cavernous darkness, a rampant insecurity and uncertainty: terror alert. The problematic is more maddening than usual because what has been happening outside of conflict zones is not the result of a declaration of any war as such; or of any economically-provoked recession or depression; or of a major natural, chemical or nuclear disaster. The reprehensible is not comprehensible, not any more it seems-not to a mind-set fed on rational analysis which has in varying degrees valued causality, continuity, difference, achievement and individual merit, a dialogue even across ideologies and purposeful resistance, as building blocks of, dare I say it, modern civilization.

A mind-set which is heir to the Renaissance and the Enlightenment, declarations of right, of citizenship, to the moulding of a liberal, humanitarian self-consciousness, be it romantic or realist, artistic or pragmatic, to the industrial and-increasingly at breakneck speed - the technological and communications revolutions, for much of the past two centuries or so, and earlier still, as Paul Hazard's critique of the European mind in the seventeenth-century was among the first to show. ${ }^{7}$ Even so, we were largely in the rational realm, not capriciously blowing up historical, spiritually revered monumental works of art, Taliban-style, notwithstanding pleas by many a mufti around.

Current events, by what generally comes across through the mass media as a shar'ia-minded absolutist if not desperate "anti-Western" militancy, defy such assumptions as had become intrinsic to the secularized mind of a rational self; where church and state became separate; women as liberated as men, or almost so; public and civic education to be had for all; the markets largely free and choice-based, but with social legislation to ensure at least basic human needs; often push-button or cash-and-carry services; and where open debate, like alternating succession through party politics, came to characterize, to animate civil society and public life. No longer a slave or a serf, a beggar for alms, an illiterate or a blind fanatic, the person believed himself to be emancipated, legitimized and recognized as an autonomous self with free will, hopefully linked through family and community, within the parameters of a corpus juris fairly balancing duty with right. These core values of what, for want of a better term, one might call "Western civilization," were hard fought for, gained at the expense of slash-and-burn vandalism, land-tied feudal tenure, inquisition, slavery, dynastic rule by divine right, arbitrary arrest and taxation, class privilege, political repression, religious persecution, totalitarianism, and foreign occupation no less.

Is this what is at issue today? Given that the "East" no longer means what it generally did until 1989, is it really the utter rejection of all this that is so undermining the future of co-existence, of discourse, between the so-called West and radical exponents from the so-called Orient? When Edward Said, a Palestinian New Yorker, was asked for his views about September 11, here is what he replied:

It was an implacable desire to do harm to innocent people. It was aimed at symbols .... But it was not meant to be argued with. It wasn't part of any negotiation. No message was intended with it. It spoke for itself, which is unusual. It transcended the political and moved into the metaphysical. There was a kind of cosmic, demonic quality of mind at work here, which refused to have any interest in dialogue and political organization and persuasion. This was bloody-minded destruction for no other 
reason than to do it. Note that there was no claim for these attacks. There were no demands. There were no statements. It was a silent piece of terror. This was part of nothing. It was a leap into another realm - the realm of crazy abstractions and mythological generalities, involving people who have hijacked Islam for their own purposes.

But then he added:

It is important not to fall into that trap and try to respond with a metaphysical retaliation of some sort... ${ }^{8}$

To suggest that such a cynically calculated, ruthlessly executed plot, with all the trappings of modernity, had no message, may be understandable as an intellectual's reaction, but does it not miss a point? Was it nihilist then? Was it masochistic? Did these latter-day kamikaze die and kill in vain? Was it simply a profound hate writ large? Was it an exaggerated, irrational fear of penetration and control? Or a bid for supremacy in an opposite direction? Had the load miscarried, and the camel broken its back? Or had Saudi anti-infidel school textbook wahabism come of age?" What about so many other anti-American incidents in the recent past, attributable to angry feelings, broadly emanating from smouldering cinders in the same region over time? Did Madrid in 2004, on the eve of an election (the result of which it probably altered) bear no message either? But has such a wholesale suicidally-driven confrontation-strangely recalling a Luddite reaction, an eerie neo-crusade, if not a mental asylum run riot-ever been so central, so pervasive, so apparently single-minded and compact, so spread?

No, it probably has not; and hopefully it is not. Constantinople, Granada, Vienna were crystallized points in time and place. Historically, as much as six centuries later, this is both wider and narrower. Wider, because of visually evocative, if factually revolting and perplexing, mass communications exposure. Narrower, because globalization in situ is not as rampant or didactic as it may have seemed. While hardly being a surface phenomenon, a Braudelian crest-foam, equally it has not seeped into the bone of people in hall and cot everywhere. A critical awareness, a conscientization, an adjustment remains possible, so what forms that response takes, and where, becomes crucial, however difficult and delicate. In various parts more than in others, such as the Mediterranean, regionality remains discernible, meaningful, firmly rooted, cherished, and potentially maturing.

We have to watch out lest we "Americanize" the historiography of the Mediterranean region, and of the Middle East with it. While these parts of the world may roll into one as seen from afar or fleetingly, their regional locations, their histories and sensibilities are distinguishable, as are their societies. Let me locate myself: I have lived and worked on both sides of the Mediterranean Sea (and much farther away too) but I was born in the middle of it, in the Maltese Islands, which is where I currently reside. Notwithstanding considerable influence which the USA continues to exercise in Europe through NATO, economically, financially, and otherwise, we also have to watch out against equating the USA with "old-time" Europe and Europeans as "the West." The increasingly evident differences and distances, emerging as the EU grows stronger, do not and will not relate simply to America's war against Iraq, to the Israeli Wall, Kyoto, the International Criminal Court, entrepot quotas. Or as to whether or not, when and perhaps how the EU should admit Turkey as potentially its largest member, in accordance with the advice publicly proffered by a serving American grandee on a recent visit there-and that ostensibly in the name of Christian-Islamic reconciliation, or was it the secular state, 
exactly at the same time that pockets of post-Saddam Iraq continued to blow up non-stop.

Finally, we have to be careful about how we lump America and Americans together, as if they were another umma, which they most certainly are not. I was a visiting professor in Indiana in the winter of 2003 and I did not meet one single American colleague, male or female, who favoured a pre-emptive war against Iraq. By the same token, the stereotyping media tendencies on the so-called "Arab world" or more pointedly of "Islamism" badly need checking out on all sides: many such generalizations clearly would not be acceptable to most Muslims and to most Arabs, not all of whom of course are Muslims, even less of whom are conservative fundamentalists, still less armed fighters to the death. Such a deeply anchored and charged debate, historically and philosophically beyond the scope of this paper, featured in some of the workshops at the ISSEI conference at the University of Navarra, Pamplona, in 2004.

In the general context of it, from which one cannot escape, let me concentrate briefly on some historical aspects of cross-cultural discourse and socio-political realities in the Mediterranean, excluding here the seemingly ever-boiling Near and Middle Eastern cauldron. Mined as it has been (and still is in some important respects) this more European-Mediterranean focus may offer us rather more hope than that suggested either by Huntington's generalized confrontational drill, ${ }^{10}$ or by Esposito's pacifist, reconciliatory apologetics. ${ }^{11}$ The sabre-rattling and crusader-like drawing of battle lines is frighteningly reminiscent of old believer-infidel antagonisms, but for all that one cannot solely and simply blame the West.

Over time, beyond the mediaeval period, scholarship offers some examples across the region of a generally fairly open, searching disposition, at best one mutually appreciative of distinctive cultural norms and forms, without in-built instincts of hostility or aggression: there was difference, diffidence, competition and often a rightful hurt, but not a discourse necessarily predicated on mutual annihilation. ${ }^{12}$ The co-existence in Andalucia, although not always ideal, is the most noted and quoted; it is evident even in periodized musical genres, as in a researched CD called Tres Culturas, which you can buy in the Alhambra. On the southern shores, the best exponent of such investigative, imaginative scholarship would be the widely-travelled Ibn. Khaldun, although there are various others, like Masoudi, Tabewi, Ibn Battuta. In the Enlightenment period, an interesting specimen is al-Jabarti, the Egyptian historian, who saw the positive benefits that could result from empirical research and experimentation, such as Bonaparte's expedition of 1798 embarked upon, the looting notwithstanding. ${ }^{13}$ Not unlike Peter I, Jabarti realized that if Arabs hoped to resist a Western advance, checking or reversing the earlier Arab one, they had to emulate it, to pull up their socks and modernize, even westernize in their own ways. Alternatively they could only retreat within themselves, seeking their potential strengths there. To Peter, the "West" was Sweden; to Jabarti, it was France. In both cases, there was an indigenous resistance to such "westernization," creating an ongoing tension in nation-building; but nothing stirred up people better than an invasion, whatever its reformist, liberating garb.

Any tentatively positive, willing dispositions to European inquiry and endeavour often would be let down by Western Europeans, who in the nineteenth-century came to pretend they were superior, irreproachable, or who confused science and industry with natural selection on a racial scale. However, other researchers on the other side of 
the water, such as Gian Battista Vico, teased out unconventional sources of nationality, self-esteem and belonging, which in time influenced learning and self-consciousness generally, while others still were fascinated by the Orient, not always in a patronizing or dismissive way. Moreover, Bonapartism aroused a wave of national self-consciousness in Egypt no less than on the European mainland, it being unable to match its theories with its practices.

In referring to writings by Stora, Berque, Daoud, al-Bishri and others, Francois Burgat has noted that if, in spite of the re-emergence of a modernizing dynamic in the eighteenth-century, Islam had ceased to be modernized, "it is perhaps because the societies that had been traumatised by the Western invasion no longer believed that the changes entailed by this modernisation displayed any endogenous characteristics, but rather that they had been triggered by foreign influence." 14 While Jacques Berque drew attention to the reification of tenth-century Muslim law, alias the shari'a- "while the world has moved on, the law has been left behind"-al-Bishri tried contextualizing this as a reaction:

... the conservatism of Islamic thought began to emerge and become more resolute, as a result of the influence of its defensive and defiant attitude and out of fear of being uprooted, as well as out of its determination to protect its beliefs, its framework of references and the sources of its civilisation. Any display of dogmatism was simply a result of the obsessive fear that it would be usurped... So, how can you go forward when all your energy is taken up with defending the status quo and holding your position? $?^{15}$

Corsairing, which had been practised for centuries from one end of the Mediterranean to the other-by Christians as much as by Muslims-led ironically to the first ever war undertaken by the brand new USA navy, in the Mediterranean, against the Barbary Moors, who were intercepting and harassing American vessels, on occasion tearing up the stars and stripes of a proud new nation-state, recently rid of its British overlords. With hindsight, it was a rather ominous beginning, although Gibraltarian, Sicilian and especially Maltese ports readily sheltered and provisioned the sojourning American ships and their crews.

More serious was the superior attitude and manner shown by Europeans, when France, Britain, later Italy, and to some extent Spain and Germany, sought out territory in Northern Africa for themselves. This was greatly reinforced by European expansion southwards, on one shallow pretext or another. Native resistance, however courageous and heroic, could not beat back the much better-armed, more richly-endowed European invaders, with their sturdy ships and drilled armies of musket-laden soldiers, as the Ottoman Empire declined further. In Algeria after 1830 and in Tunisia after 1881 the French sought not only to govern and to control these territories but to colonize and to settle them with their own imported kith and kin from "home." Thus they took possession of their more fertile hinterlands as well as of their Mediterranean ports and harbours. What this meant was that, at the moment of impact, any co-existence was forced by the ruler over the ruled, the foreign colon over the native fellah, the occupier over the traditional owner or grower, the urban or cosmopolitan over the nomadic or peasant, who at best became his employee or assistant. Culture clash took many forms: ethnic, linguistic, religious, economic, financial, and ultimately political and military. Difference was for one a distinctive badge of power, of conquest; for the other, possibly 
even in his own eyes, a statement of weakness, of inability to hold his own ground, literally and metaphorically, and thus a mark of inferiority.

As successive generations of colons were born and raised in these "French" territories, the interaction between the races grew proportionally, but never sur le pied de l'égalité. Although successive French administrations and governorships tried to integrate Algerians and Tunisians by regarding their countries as "départements" of the supposed mothercountry, and through Frenchification policies in education, employment and citizenship, the opportunities offered by assimilation appealed to a minority. Moreover, as was wont to happen, many of those who benefited from an education in France which would not have been possible in North Africa, returned home invigorated by the ideas and manners which they had absorbed, conscious of the opportunities enjoyed in France, and equally bent on seeing comparable improvements undertaken in their own countries. These lived experiences were probably more penetrating than the civilizing missions of empirebuilders, governors, politicians, educators, ecclesiastics. Several who had been similarly educated and exposed saw advantages in a better-organized integration with France, while retaining an autonomous "national" standing. In Algeria, for example, contrasting positions were taken, broadly speaking, by the parties of Ferhat Abbas on the one hand, and of Messali Hadj on the other. The former, considered a liberal and a moderate, initially favoured integration; the latter, considered a communist and an extremist, favoured independence.

What this showed was a cross-cultural dynamic, a dialectic even, resulting from such modernization as foreign occupation had brought about. It also showed that different social classes and political ideologies emerged and engaged each other under a colonial umbrella. In "French" North Africa, there was a third factor: that of the colons, most of them French, others who were Italian, Maltese, Spaniards, Portuguese. To the extent that the metropolitan administration in Paris or its representatives in the territory sought to appease demands by the indigenous Arabs, the colons protested fearing that they would lose their status or indeed their rights, businesses, jobs and properties, at which they had worked hard. Like Anglo-Indians after 1947, or white Rhodesians after 1980, these pieds-noir eventually came to belong nowhere completely: kicked out of Northern Africa bag and baggage after independence, they were hardly welcomed enthusiastically in France, where in most cases they had never lived or even been. The situation in Tripolitania and Cyrenaica became comparable in the first decades of the twentiethcentury. Other triangular dialectics were at work: in Egypt between the British, the khedive and the Wafd-led opposition; and later, differently again, in Palestine during the mandate. Pieds noir above all carried a part of Africa with them in their hearts and memories, and another part-for those who had not been originally French - of the first "old" country of origin, to which ironically they sometimes felt a warmer, more authentic relationship. 16

A similar movement in reverse has been happening in the past years, and seems set to grow, as hundreds of thousands of North Africans travel, usually illegally, to the former so-called mother-countries. The result is, as we know, that there are now some four million Muslims, mostly Maghreb Arabs, in France, with certain areas of concentration and of contention, such as Marseille, drawing the strongest vote for anti-immigration parties, who in turn feel swamped themselves. Historically speaking, however, if we take a long view, the North-South migration and settlement movement is being 
complemented, probably more permanently, by a South-North one. Once again the question is: what co-existence of differences is possible and how manageable is that?

In the case of Italy, it is mostly migrants from former Italian-held territories such as Eritrea and Somalia who flock there. Relatively few Libyans do so, mainly because the economic situation in Libya is better, which while not at all democratic, is oil-rich and politically stable. Libya, however, is a conduit for a sea of clandestine emigrants from other parts of Africa. In July and August 2004 Italy's Minister of the Interior Giuseppe Pisanu repeatedly stated that there were currently as many as two million such persons waiting to be provided with "any old wreck" by human smugglers, for them to travel to the European mainland, or elsewhere in the region. Turner's bad dream about dealings in human cargo had not quite ended with the abolition of slavery.

Clearly enough, however, these masses of people are not intent on distancing themselves from Europe's lifestyle or its institutions, much less are they bent on hating or destroying them. On the contrary, they are drawn to Europe like never before because they feel that in their own post-colonial countries they are worse off than they would be in a Western European country (or in North America if they got a chance to go there). They pay whatever money they have saved and sometimes risk their lives to leave home and travel to Western Europe, usually illegally, in the hope however that somehow or other they might get jobs, shelter, humanitarian aid, and sooner or later regularize their position in whichever European country they end up, preferably a Schengen one. What this also shows is how far we are from a situation where the vaunted four freedoms of modernity are at all evenly spread in the world: that comprises many African countries which are potentially far wealthier than several European ones, if only they functioned differently. Liberal democracy may have won in America and Europe, where the cake has spread, but that uneven situation outre mer creates new tensions elsewhere which could be a powder-keg of envy, resentment and disorientation as images of comparative affluence and indulgence reach audiences who live in poverty even when their own states may be rich, or who see that they lack such freedoms as might become possible if they got rid of incomparably rich ruling elites, seen to be propped up by America, true or false.

The world's top oil producer in the Middle East may be one such case, if only to an extent - and paradoxically, given its own hardline theocracy and its munificence in financing mosque-centred would-be replicae on European soil and elsewhere. The cultural penetration of secularism, individuality and the pleasure ethic, coupled with the airing of all kinds of views, consumer products and shows offering choice, can be seen or portrayed as an upset of the strict morality desired by those who uphold fundamentalist versions of Islam, and their own key positions within its institutions: an onslaught on Allah's will.

In a published interview monitored by the $\mathrm{BBC}$ two years ago, one Iraqi Kurdish leader condemned democracy "from start to finish," as this violates Islam's law as desired by God. "Islam," he said, "believes that all the foundations of democracy are blasphemous." 17 But in fact various other reformist Arab thinkers are still digging away, more soberly and subtly, as indeed others had done before them, in attempts to reconcile Islam with modernity, even as in Iraq several outspoken exponents of civil society, especially intellectuals and academics, have been murdered in the past year alone. Addressing Hausa and Fulani fighters in medieval garb on tasselled horses and camels in 
Sokoto, Nigeria, as they clutched swords, spears and battle axes, in a bicentenary commemoration of an 1804 battle, West African leaders, Christian and Muslim, held that anyone who burnt places of worship, either mosques or churches, was "an infidel"; that nineteenth-century jihad had "nothing to do with today's rampages"; leaders should value "unity and peaceful co-existence"; the spread of Islam valued knowledge but modern day religious violence didn't, "only creating more problems."18

Immediately after the 1967 Arab-Israeli war, which led to Nasser's resignation, the Syrian poet Nizar Qabbani wrote verses which were recited and sung throughout the Arab world at the same time that, in Tariq Ali's words, they "outraged the scribes of the state and the secret police in every Arab capital." ${ }^{19}$ Verse 17 read thus:

If I knew I'd come to no harm,

And could see the Sultan,

This is what I would say:

"Sultan,

Your wild dogs have torn my clothes

Your spies hound me

Their eyes hound me

Their noses hound me

Their feet hound me

They hound me like Fate

Interrogate my wife

And take down the name of my friends.

Sultan,

When I came to your walls

And talked about my pains,

Your soldiers beat me with their boots,

Forced me to eat my shoes.

Sultan,

You lost two wars.

Sultan,

Half of our people are without tongues,

What's the use of a people without tongues?

Half of our people

Are trapped like ants and rats

Between walls."

If I knew I'd come to no harm

I'd tell him:

"You lost two wars.

You lost touch with children.,20

Democracy could be conceived more simply and ideally as a communal covenant where the family, prayer and dress codes remain intact, with a provision for care of, say, a widow, within the extended family network, as a human right; although women's rights, not simply as a fashion wardrobe, remain an overriding concern. The group who kidnapped an Egyptian diplomat after a mosque service in Baghdad on 23 July 2004, so that Egypt would not help Iraq improve its security apparatus, call themselves: "The Lions of God's Battalions." When they released him some days later, they gave him a string of prayer beads - and a dagger. 
Is this not the same mythology to which Said referred when asked to explain September 11? But what percentage of resident Arabs, Muslims and others actually do wish Iraq, Afghanistan, Saudi Arabia, Iran to be-internally-intolerant, monolithic, fundamentalist Islamic states and-externally-militantly, violently, ruthlessly anti-Western, even anti-European, as if the world had not moved mentally and institutionally from the mediaeval to the modern? In a lecture at St John's Gate, Jonathan Riley-Smith reminded us that Saladin, a Kurd, was more ethical in his treatment of prisoners of war than Richard I, the Lion Heart; ${ }^{21}$ but that's not much to go by either, and it was so long ago.

The North African countries, closest to Europe geographically, are also closer to it in other ways than such parts of the Middle East. As shown by Braudel, Rodinson, Moscati, Horden and Purcell, Abulafia and others, the mixing, mingling and trading, the sharing and even the quarrelling experienced by those on the southern and the northern coasts and shores of the Mediterranean has been so considerable and for so long that it has rubbed off, to some extent, on either side. These are not mainly people of the desert, not nomads in tents, but seafarers and coastal inhabitants of port cities, petty vendors and dealers who can travel by boat. All the way from ancient times to the present, such interactions have been constant because they have been necessary. The produce of the region affects the food, the climate the dress and life in the open air, the sea occupations and hobbies. Of course they have fought, and they have experienced the divide between the long competing religions, especially Christianity and Islam. But, on the whole, the Ottoman Empire was tolerant of minorities, including religious minorities.

In his study "L'Evolution interne et les influences externes dans l'histoire culturelle de la Méditerranée," Maxime Rodinson held that adaptation was not restricted to pre-existing elements in society but was a synthesis comprising new elements in the face of challenges and innovations susceptible to development, ideas as well as objects. $^{22}$ One such aspect of secularization in Northern Africa clearly has been "Western" tourism, sustained increasingly on a mass scale, and not limited to sun-bathing on remote beaches.

Albert Camus may have been dreaming when he saw the Mediterranean as a role model for co-existence, because clearly this sea has been as much of a divider as it has been of a unifier. In a partial critique of Braudel's more holistic thesis, Horden and Purcell would argue that in the twentieth-century modernization has had a disintegrating effect. On the other hand, however, the absorption of new methods and techniques need neither demolish the peculiar characteristics noted by Peristiany and Pitt-Rivers, nor otherwise make the region seem backward and exotic, as feared by Herzfeld and Pina-Cabral, precisely because in certain particularities it remains distinct. Even in dissonance, there is a curious unity. The three competing western-moving religious cults to which the Mediterranean gave birth always meant to adore the same one God; alas how many misdeeds have been committed in his name. They are all, according to the Koran, people of the book (ahl al-kitab), all pledged religiously to do good and to shun evil. However important it may still be in varying degrees, religion is by no means its sole defining socio-cultural quality.

Those who, like Habermas, have held that rather than cultural pluralism it is cultural homogeneity that constitutes the world's most precious legacy and aspiration, are misled, 
because "global civil society" and a universal citizenship do not happen by fiat or in vacuo, however desirable individual rights, the rule of law and market economies may be. The clinical insertion of bodies felt to be foreign by a metabolism need not work out as a recipe for integration and healing. It has been held by others that, on the contrary, as the number of living languages declines, protective barriers are broken and nests destroyed, insecurity, disorientation and distress conspicuously increase. Hedley Bull, Featherstone, Robertson, Hannerz, Latouche, Cassano, Escobar and Marquand, among others, have come to see the rhetoric of the "global village" as a failure, leading to segmentation, hybridization, creolization, especially in populations who were culturally weak or who long have been subjected to colonial hegemony. In Apparenenze $e$ liberta', Escobar prescribed that while keeping away from ethical universalism and religious dogmatism, Mediterranean modernity should be inspired by a tolerant, inclusive ethical-religious "pluriversalism." Fundamentalism, the message goes, is not only of the religious kind. Beware, too, the doctrinal fundamentalism of modernity: consumerist, acquisitive, competitive, productive, efficient, speedy, damaging nature and environment in its sweeping stride, aggressive and assertive. While noting that Al Farabi, Al Kindi, Avicenna and Averroes were philosophers not theologians, Zolo has visualized a re-elaboration of Mediterranean traditions wherein bonds of civil and political allegiance remained strongly affected by religious imagery; but abandoning religious ethnocentricism. The overcoming of dogmatic thought calls for an inter-cultural dialogue, which does not entail a denial of each people's cultural roots. ${ }^{23}$

What Camus envisioned for "la nouvelle culture Méditerranéenne" remains meaningful if his context is re-drawn. He was a Frenchman in "French" Algeria, an antiFascist, a Communist. He saw "le pensée de midi" as a third way between European fascism and Russian collectivism. ${ }^{24}$ Both have lost out. A central flaw in his Euromed vision, influenced as it was by "algérianité," was that it largely excluded the Arabs. As Davison has noted, Camus tried to group together the Maltese, Spanish, Italian and French settler populations, hoping for an eventual miscegenation, the hybrid becoming a standard. The neo-Homeric fascination by the common shores of a Middle Sea-Paul Achard spoke of L'Homme de la $\mathrm{Mer}^{25}$-inspired the name of the journal: Rivages. Camus' unifying Mediterranean, Eurocentric and anti-Nordic though it was, would be based on man, human values not Christianity or the papal Rome of the Holy Roman Empire, creating an accord between the peoples and the countries of its shore-lines. It would be a "terrain de rencontre" where the most diverse spirits, yesterday's great writers known and unknown, by means of numerous translations of texts-Spanish, Italian, Arab-would rediscover their youth. This idealized vision was more poetic than historical because even the similarity of lifestyles-he mentions the Spanish siesta for example-hardly reconciled the European Mediterranean to the "Orient." However, any attempt at motivating an ongoing cultural reapprochement today, in post-colonial times, and within a regional policy framework, could do worse than dismiss Camus:

L'Afrique du Nord est un des seuls pays ou l'Orient et l'Occident cohabitent... le génie méditerranéen jaillit peut-être de cette rencontre unique dans l'histoire et la géographie née entre l'Orient et l'Occident... A des hommes méditerranéens, il faut une politique méditerranéenne... Une nouvelle culture méditerranéenne conciliable avec notre ideal social est-elle réalisable? Oui. Mais c'est a vous d'aider à cette réalisation. 
In this endeavour, some core values would still have to be respected: the quality of form and of thought, an ordered and harmonious miscellany "sans laquelle rien de vivant ne se trouve etre communicable."

Let it be noted that the Mediterranean here is seen in terms of a North-South rapport between Southern Europe and Northern Africa; there is no reference to the Arabian peninsula or to the "Middle East," as an English historian like John Darwin would much prefer to call it, and as do those more concerned with metropolitan power ploys from outside the region, including London and Washington, rather than with the sinews of texture within it.

If we look at Egypt, Tunisia or Morocco today, they are noticeably more secular, open and tolerant than some other Middle Eastern countries. Education has spread; television admits of some slight plurality; on the whole the press may be said to be arguably semi-free; travel, tourism, even sport, especially football, are better developed as popular pursuits, although many of their most gifted contemporary thinkers and writers, including Egyptian ones, have for various reasons moved to the West. There is currently none of the unspeakable systematic mass brutality which has come to be associated with the Middle East. Is there not the prospect that most North African countries, possibly to include Libya eventually, become progressively more open, slowly, as the EU's new "Agadir" policy of development aid tied to a principle of conditionality, particularly with regard to human rights, takes effect? And as the gravitational pull of the nearby EU-economic, cultural and political-picks up momentum in a slowly growing common free trade area? In this older rather than newer neighbourhood, that remains a slow progression even now, with setbacks and reverses, the perfunctory battling the essential, and harbouring no guarantee of any generally unfolding linearity towards pluralism particularly in the political sphere, at least not on European post-war models. There is, too, a prospect that the third pillar of the 1995 Barcelona Convention finally gets off the ground and works at the seams towards greater cross-cultural knowledge and mutual appreciation and understanding, through such means as the Euromed Foundation now being set up in Alexandria. Soon this should start networking in spheres to include archives, libraries, museums, book translations, school textbooks, comparative religion, migration studies, the press and media, film-making and the performing arts. It is a tall order but it is a start, requiring as much intellect as empathy with the peoples of this region, by those aspiring to guide its progress.

If we look at the geographical margins of Europe, where cultures have overlapped and been internalized, even homogenized, I believe the hope increases further, unless there is dramatic demographic and cultural disturbance because of overwhelming illegal immigration, bursting the limits of resource, tolerance and space. Over the gamut of centuries, Gibraltar, Malta, Cyprus and some of the other Mediterranean islands and enclaves have experienced ethnic transplants, religious conversions, changed sovereignties. Today they are small, reasonably prosperous, democratic EuropeanMediterranean communities with distinct nationalities, fairly tolerant of minorities and open to a gradual evolution. As of 2004 two of them, both islands and ex-colonies, are now EU members, one rather more entirely than the other. In the course of time, these have seen the multi-lingual, multi-cultural orders of chivalry, the Italian, Turkish and Arab traders or settlers; the legacies are everywhere, in the architecture, in the complexions, even in the language. Like larger countries to their south, Cyprus, 
Malta and Gibraltar have had their integration-independence, centre-periphery dialectics, and still do.

With open frontiers in an enlarged space, the earlier rivalries between Spain and Britain over Gibraltar, between Britain, France and Italy over Malta, between Greece, Turkey and Britain over Cyprus or indeed the already somewhat reduced inter-ethnic tensions within Cyprus, seem destined to gradually wither away in a Europe of the peoples and of the regions. As a free trade area develops and a common defence and security policy takes shape, it is likely that such a Europe will be increasingly more adept at helping to solve disputes festering close to its own borders, and preventing risky remote-controlled military excursions, which could end up defeating the purpose for which they were intended.

When in his quasi-racist Sorbonne lecture in 1883 Ernest Renan had dismissed the state of Islamic culture as an obstacle to philosophy and science, Jamal ed-din al-Afghani had protested saying that one should not mistake what was admittedly a slow phase of development for a culture's inherent potential in time, past or present. Vico, who abhorred what he called "the haughtiness of nations," and probably Herder and Fichte too, would have supported Afghani. An advocate of pan-Islamic modernism and of resistance to Western imperialism, Afghani, in his prudent and pertinent rejoinder, admitted that all religions were intolerant, each one in its way. Both Islam and Christianity had turned against the free use of reason and thus stifled scientific progress at some point of their history. As Christianity had preceded Islam by many centuries, he hoped that Mohammedan society, whose past achievements were acknowledged, would succeed someday in breaking its bonds and marching resolutely in the path of civilization. "No, I cannot admit that this hope be denied to Islam."

While opposing positivism and materialism, and holding Islam to be the best religion, Afghani more than Khaldun distinguished between religion and philosophy, taking a dim view of any culture where no such distinction was drawn. But he was not sure how it would turn out. "So long as humanity exists," he wrote, "the struggle will not cease between dogma and free investigation, between religion and philosophy: a desperate struggle in which, I fear, the triumph will not be for free thought, because the masses dislike reason, and its teachings are only understood by some intellectuals of the elite, and because science, however beautiful it is, does not completely satisfy humanity, which thirsts for the ideal, and which likes to exist in dark and distant regions that the philosophers and scholars can neither perceive nor explore."26

A freemason of the Mazzinian genre who opposed despotism and foreign rule, al-Afghani fought for the regeneration of Islam in Egypt and other countries in the region. The possessor of great personal charm, he inspired his disciples with a desire to stem the tide of European influence on the Islamic world by reinvigorating Islam through a return to its origins and by achieving a political union of the Muslim peoples under constitutional governments. He tried to infuse his many disciples with a truer appreciation of the more liberal principles of government. Pro-independence journalists inspired by al-Afghani in Egypt, in France and elsewhere included Jews, Syrian Christians, and his best-known follower Muhammad Abduh, who opposed violence. ${ }^{27}$ Jamal al-Din al-Afghani was a great Muslim reformer and critic who spent much of his life travelling and teaching in Mediterranean and European countries, who was exiled more than once, who was buried in an unknown grave; but he is one legendary figure who can still serve 
as a guiding light to all those blinding themselves to reality and to reason, seeking solace, vindication and an elusive redemption instead through murderous myths.

\section{NoTES}

1. Keith Windshuttle, "Historiography and Civilization," Washington Times (9 May 1999), reviewing Donald R. Kelly, Faces of History: Historical Inquiry from Herodotus to Herder (New Haven: Yale University Press).

2. Koichiro Matsuura, The Future of Valtes (Paris: UNESCO, 2004), inspired by Michel's study.

3. On Ibn Khaldoun see Charles Issawi and Oliver Leaman, (London: Routledge, 1998).

4. For an inspiring reappraisal see Peregrine Horden and Nicholas Purcell, The Corrupting Sea: $A$ Study of Mediterranean History (2000) and more recently David Abulafia, ed., The Mediterranean in History (2003). See also N. Purcell's 2004 article in the Mediterranean Historical Review, in which he argues that the Mediterranean has no centre; and of course Fernand Braudel, La Méditerranée et le Monde Mediterraneen à l'epoque de Philippe II (Paris: 1949) and subsequent editions; the main English translation is by Sian Reynolds (1972), and an abridged English version by Richard Ollard (1992).

5. See Fred Halliday, "America and Arabia after Saddam," in Open Democracy on the net, based on his LSE lecture of 6 May 2004 entitled "The Middle East after Saddam Hussein."

6. Kenneth Clark, Civilization (1969), 219.

7. Paul Hazard, La crise de la conscience européenne, 1680-1715 (Paris: 1935), translated into English as The European Mind. See also Christiane Villain-Gandossi, ed., L'Europe a la recerche de son identité (Paris: 2002).

8. See Said's interview with David Barsamian in The Progressive (November 2001).

9. For an incisive update see David Gardner, "Time is not on Saud's side," Financial Times Weekend (31 July-1 August 2004): 1-2, but there is now a growing literature on varieties of Islam, modernization, the West, and fundamentalism, on which see further below.

10. Samuel P. Huntington, The Clash of Civilizations and the Remaking of World Order (1996).

11. John L. Esposito's books include, among others, Unholy War: Terror in the Name of Islam; The Islamic Threat: Myth or Reality? Islam and Democracy.

12. The theologian Ibn Tamiyya, a forerunner of radical anti-infidel Wahabi thinking, as practised by the world's first "modem" Muslim fundamentalist state, Saudi Arabia, died in 1328.

13. For a discussion of al-Jabarti see Edward Said, Culture and Imperialism (1993), 38-40, 304.

14. Francois Burgat, Face to Face with Political Islam (London: 2003), first published as L'islamisme en face (Paris: 1996), 154-5.

15. Tareq al-bishri in an interview with Burgat, Ibid., 155. See Geoffrey Barraclough, "The Revolt against the West," in Decolonization: Perspectives from Now and Then, ed. Prasenjit Duara, chapter 10, in the series "Rewriting Histories" (London: Routledge, 2004).

16. For a Maltese-Algerian dimension to this see for example the writings in French of Laurent Ropa and more recently the poetry by Pierre Dimech.

17. Mala Krekar interviewed by Hawlati, Al-Sulaymaniyah, in Sorani Kurdish, 11 February 2002, as reproduced in The Financial Times.

18. A syndicated AP report from Sokoto, Nigeria, in June 2004, quoting, among others, President Olusegun Obasanjo, a southern Christian; Sultan Mohammed Maccido; and Mohammad Tambari, a descendant of Dan Fadio, who in addition to spreading piety and literacy was also quoted as saying: "there is no free place of the intellect."

19. Tariq Ali, The Clash of Fundamentalisms: Crusades, Jihads and Modernity (London \& New York: 2002), 117.

20. Ali cites it in toto, 117-22, in an English translation. Its original title is Hawamish 'ala Daftar al-Naksah (Footnotes to the Book of Setback). 
21. See my public lecture "Unity and Diversity in the Mediterranean: Some Post-Braudelian Reflections," Always on Friday series, History Faculty, Indiana State University, Terre Haute, 6 February 2003.

22. Rodinson was criticising H. A. R. Gibb's position in "The Influence of Islamic Culture on Medieval Europe," a journal article published in Manchester in the mid-1950s. (I only have a mimeographed script of this critique, given to me personally by Rodinson in 1972.)

23. See Danilo Zolo's expose "A Dialogue between the Mediterranean Cultures" in "Tradition et modernite' dans la culture mediterraneenne" (Universita' di Firenze: Centro Jura Gentium, 2003).

24. His 1937 lecture "La Culture indigène, la nouvelle culture méditerranéenne" was published in the first issue of his Jeune Mediterranee as "Politique et culture Mediterraneennes," but see Ray Davison, "Mythologizing the Mediterranean: The Case of Albert Camus," Journal of Mediterranean Studies 10(1\&2) (2000): 77-92.

25. Paul Achard, L'Homme de la Mer (1931).

26. Nikki Keddie, An Islamic Response to Imperialism: Political and Religious Writings of Sayyid Jamal al-Din 'al-Afghhani (California: University of California Press, 1968), 183, 187.

27. Jacob M. Landau, Parliaments and Parties in Egypt (Tel-Aviv: Israel Oriental Society, 1953), $80-2,86$. 